\title{
AN EXAMPLE OF CELLULAR HYPEROSMOLARITY ${ }^{1}$
}

\author{
BY L. G. WELT, J. ORLOFF, 2 D. M. KYDD, AND J. E. OLTMAN ${ }^{3}$ \\ (From the Department of Internal Medicine, Yale University School of Medicine, New Haven, \\ and the Fairfield State Hospital, Newtown, Connecticut)
}

(Submitted for publication December 16, 1949; accepted, April 3, 1950)

\section{INTRODUCTION}

The free permeability to water of cell membranes provides an automatic mechanism for the maintenance of a uniform effective osmotic pressure throughout all the fluids of the body. It has been assumed that the osmotic pressure is a relatively fixed value and indeed, this appears to be true under a fair variety of circumstances. Among the more jealously guarded biologic attributes is the tonicity of the extracellular fluid (1). It has been demonstrated both with respect to the red blood cell in particular and tissue cells in general that induced alterations in the tonicity of the extracellular fluid will be followed by an inverse change in volume of the intracellular fluid (2).

Yannet and Darrow (3), however, were unable to account for the distribution of water between cellular and extracellular compartments on the basis of osmotic uniformity unless there had been a change in the osmotic pressure within the cells. Elkinton, Winkler, and Danowski (4) on the basis of comparison of the movements of sodium and potassium with those of water in a series of experiments concluded that there was inactive base in the cells which could vary rapidly in amount. Although this is not unlikely, changes in cellular osmolarity need not be assigned to variations in inactive cell base. An alteration in effective osmotic pressure within the cells will arise from any change in the concentration of osmotically active constituents.

As a basis for hypothesizing that primary changes in cellular osmotic pressure may be the original disturbances leading to abnormal concentrations of sodium in the extracellular water in certain disease states, it is important to demonstrate unequivocally that large transfers of water

\footnotetext{
1 Aided by a grant from the National Heart Institute of the U. S. Public Health Service.

2 Work done during the tenure of a Life Insurance Medical Research Fellowship.

${ }^{3}$ Clinical Director, Fairfield State Hospital, Newtown, Connecticut.
}

between compartments can be dictated by changes in osmolar concentrations within the cells. Ward and Call (5) demonstrated a respiratory and metabolic acidosis associated with increased concentrations of sodium in the serum of rats one minute after an electrically induced seizure. The rise in sodium concentration was not explained. Altschule and Tillotson (6) demonstrated that during an electroshock convulsion the plasma volume diminished. They also reported that these changes varied with the severity of the convulsions and were minimized by curarization.

It seemed quite logical that the violent muscular activity of a convulsion might be associated with an increase in cellular osmolar concentration. The data of Ward and Call (5) and Altschule and Tillotson (6) suggested that the convulsions might be accompanied by a contracted extracellular volume and secondarily an increase in concentration of sodium in the serum, which could be explained on the basis of a sharp increase in effective osmotic pressure within the cells.

The present study was designed to test the hypothesis that violent muscular activity would be immediately followed by an increase in cellular osmolarity which would necessitate a transfer of water to the cells from the extracellular fluid. This, in turn, would be reflected in an increase in the tonicity of the extracellular fluid.

\section{MATERIALS AND METHODS}

Nine patients, five women and four men, were studied during 14 separate episodes of electroshock therapy for psychotic disorders. The electroshock was administered with a Lektra machine and the dose was 225 volts applied for 0.15 second. Blood was drawn under oil from an antecubital vein just before application of the current, immediately at the cessation of the convulsion which lasted approximately 60 seconds, and, in ten instances three minutes, and in four instances five minutes after application of the current. The five female patients were each studied in two separate electroshock episodes, one unmodified and one modified by curare. The curare was administered intravenously in a dose of 20 units per 40 
pounds of body weight. The electroshock was applied three to five minutes later when the patient was unable to raise her head from the table. In each instance in which curare was used the severity of the convulsion was reduced to a variable degree; in Patient 5 it was almost totally abolished. The concentrations of sodium, chloride, potassium, and total proteins or serum dry weights were determined in each instance on each blood sample by methods previously described in publications from this department $(7,8)$. Total proteins of the serum were determined by the biuret method (9) in ten studies. In the other four studies the dry weight of the sera, in lieu of total proteins, was determined for the purpose of calculating serum water.

The serum water was calculated from the formula $\mathrm{Ws}=984-7.18 \mathrm{P}$, where Ws represents the amount of water in a liter of serum, and $P$ is the concentration of total protein in grams per cent (10). The calculations used to estimate the concentrations of sodium and chloride in extracellular water, change in chloride space, changes in intracellular sodium and potassium are described in a previous publication from this department (8). The initial chloride space was assumed to be 20 per cent of the body weight, and in view of the brief duration of each study the external balances of sodium, chloride, potassium and water were neglected. The number of osmotically effective constituents is expressed as total milliosmols, and is calculated from the formula: total milliosmols $=(\mathrm{Naww}+10) \times 2 \times 0.7 \mathrm{~W}$, in which $\mathrm{W}$ represents body weight, and the total body water is assumed to be 70 per cent of the body weight.

TABLE I

Effects of electroshock convulsion on electrolytes and water

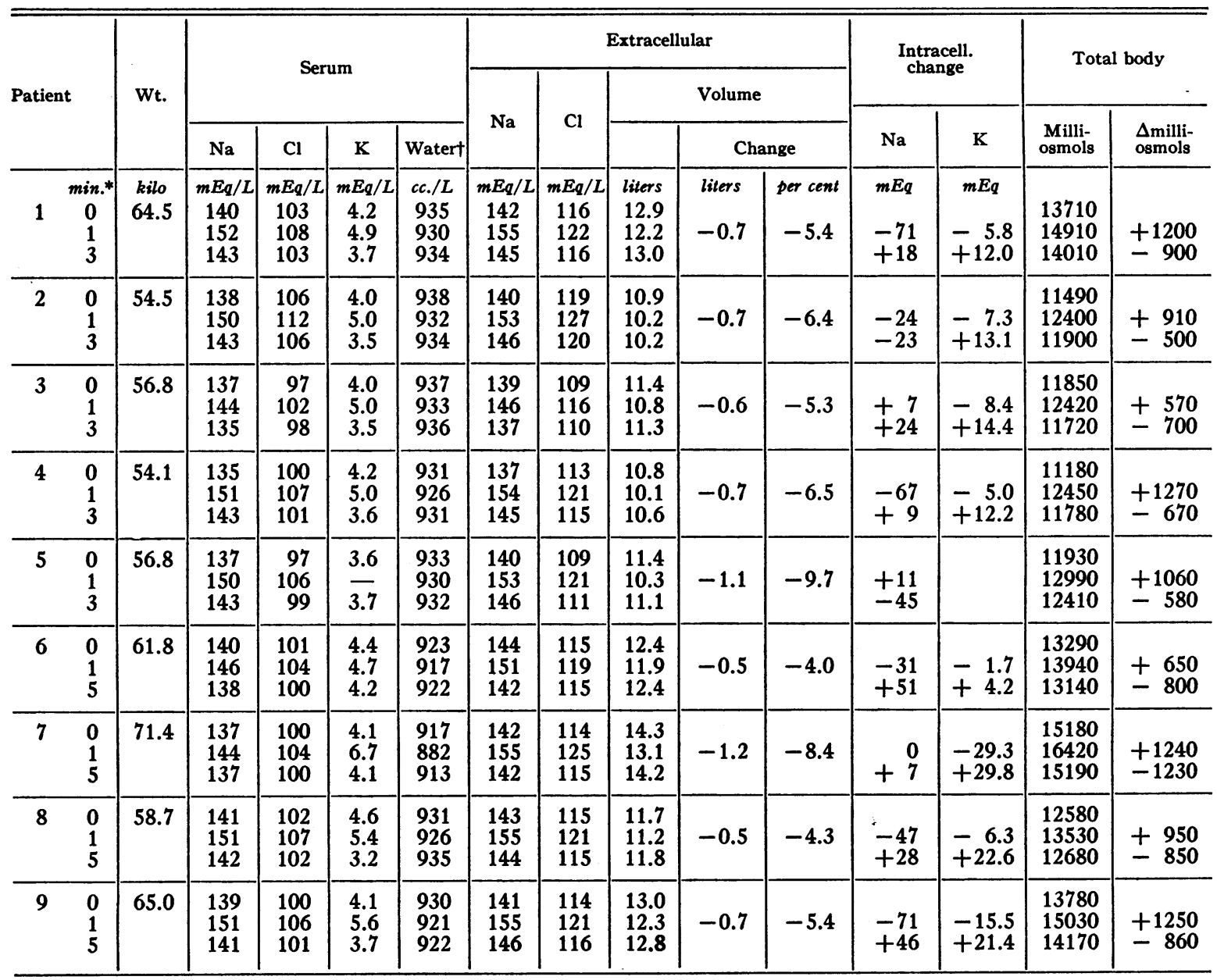

*0-just before application of the current.

1 -minute after application of the current (at cessation of convulsion).

3 -minutes after application of the current.

5 -minutes after application of the current.

t The serum water of Patients 1 through 5 was calculated from the formula described in the section on Methods. 
TABLE II

Effects of electroshock convulsion on electrolytes and water modified with curare

\begin{tabular}{|c|c|c|c|c|c|c|c|c|c|c|c|c|c|c|c|}
\hline \multirow{3}{*}{\multicolumn{2}{|c|}{ Patient }} & \multirow{4}{*}{$\begin{array}{l}\text { Wt. } \\
\\
\text { kilo } \\
65.9\end{array}$} & \multirow{2}{*}{\multicolumn{4}{|c|}{ Serum }} & \multicolumn{5}{|c|}{ Extracellular } & \multirow{2}{*}{\multicolumn{2}{|c|}{$\begin{array}{c}\text { Intracell. } \\
\text { change }\end{array}$}} & \multirow{2}{*}{\multicolumn{2}{|c|}{ Total body }} \\
\hline & & & & & & & \multirow{2}{*}{$\mathrm{Na}$} & \multirow{2}{*}{$\mathrm{Cl}$} & \multicolumn{3}{|c|}{ Volume } & & & & \\
\hline & & & \multirow{2}{*}{\begin{tabular}{|c|}
$\mathrm{Na}$ \\
$m E q / L$ \\
136 \\
142 \\
137
\end{tabular}} & \multirow{2}{*}{$\begin{array}{c}\mathrm{Cl} \\
m E q / L \\
100 \\
105 \\
103\end{array}$} & \multirow{2}{*}{\begin{tabular}{c|}
$\mathrm{K}$ \\
$m E q / L$ \\
3.7 \\
4.3 \\
3.7
\end{tabular}} & \multirow{2}{*}{\begin{tabular}{|c|} 
Watert \\
cc. $/ L$ \\
936 \\
934 \\
934
\end{tabular}} & & & & \multicolumn{2}{|c|}{ Change } & \multirow{2}{*}{$\begin{array}{l}\mathrm{Na} \\
m E q \\
+3 \\
+27\end{array}$} & \multirow{2}{*}{$\begin{array}{c}\mathrm{K} \\
m E q \\
-5.2 \\
+6.4\end{array}$} & \multirow{2}{*}{$\begin{array}{c}\begin{array}{c}\text { Milli- } \\
\text { osmols }\end{array} \\
\\
13670 \\
14240 \\
13800\end{array}$} & \multirow{2}{*}{$\begin{array}{l}\Delta \text { milli- } \\
\text { osmols }\end{array}$} \\
\hline 1 & $\begin{array}{c}\min . * \\
0 \\
1 \\
3\end{array}$ & & & & & & \begin{tabular}{c|}
$m E q / L$ \\
138 \\
145 \\
139
\end{tabular} & \begin{tabular}{c|}
$m E q / L$ \\
113 \\
118 \\
116
\end{tabular} & $\begin{array}{l}\text { liters } \\
13.2 \\
12.6 \\
12.9\end{array}$ & $\begin{array}{l}\text { liters } \\
-.6\end{array}$ & $\begin{array}{l}\text { per cent } \\
-4.5\end{array}$ & & & & \\
\hline 2 & $\begin{array}{l}0 \\
1 \\
3\end{array}$ & 54.6 & $\begin{array}{l}138 \\
143 \\
136\end{array}$ & $\begin{array}{l}103 \\
107 \\
102\end{array}$ & $\begin{array}{l}3.4 \\
4.3 \\
3.4\end{array}$ & $\begin{array}{l}938 \\
934 \\
937\end{array}$ & $\begin{array}{l}139 \\
146 \\
137\end{array}$ & $\begin{array}{l}116 \\
120 \\
114\end{array}$ & $\begin{array}{l}10.9 \\
10.6 \\
11.1\end{array}$ & -.3 & -2.8 & $\begin{array}{l}-18 \\
+11\end{array}$ & $\begin{array}{r}-8.2 \\
+7.6\end{array}$ & $\begin{array}{l}11400 \\
11900 \\
11280\end{array}$ & $\begin{array}{l}+500 \\
-620\end{array}$ \\
\hline 3 & $\begin{array}{l}0 \\
1 \\
3\end{array}$ & 56.8 & $\begin{array}{l}136 \\
144 \\
140\end{array}$ & $\begin{array}{r}97 \\
102 \\
98\end{array}$ & $\begin{array}{l}3.3 \\
4.5 \\
3.2\end{array}$ & $\begin{array}{l}941 \\
939 \\
940\end{array}$ & $\begin{array}{l}138 \\
146 \\
141\end{array}$ & $\begin{array}{l}109 \\
114 \\
110\end{array}$ & $\begin{array}{l}11.4 \\
10.9 \\
11.2\end{array}$ & -.5 & -4.4 & $\begin{array}{l}-20 \\
+2\end{array}$ & $\begin{array}{l}-11.4 \\
+13.0\end{array}$ & $\begin{array}{l}11750 \\
12390 \\
12000\end{array}$ & $\begin{array}{l}+640 \\
-390\end{array}$ \\
\hline 4 & $\begin{array}{l}0 \\
1 \\
3\end{array}$ & 55.0 & $\begin{array}{l}137 \\
144 \\
139\end{array}$ & $\begin{array}{r}98 \\
100 \\
100\end{array}$ & $\begin{array}{l}4.2 \\
4.6 \\
3.6\end{array}$ & $\begin{array}{l}930 \\
927 \\
929\end{array}$ & $\begin{array}{l}140 \\
148 \\
142\end{array}$ & $\begin{array}{l}111 \\
114 \\
113\end{array}$ & $\begin{array}{l}11.0 \\
10.7 \\
10.8\end{array}$ & -.3 & -2.7 & $\begin{array}{l}-54 \\
+56\end{array}$ & $\begin{array}{r}3.2 \\
+10.4\end{array}$ & $\begin{array}{l}11510 \\
12160 \\
11680\end{array}$ & $\begin{array}{l}+650 \\
-480\end{array}$ \\
\hline 5 & $\begin{array}{l}0 \\
1 \\
3\end{array}$ & 56.8 & $\begin{array}{l}137 \\
137 \\
137\end{array}$ & $\begin{array}{l}101 \\
101 \\
101\end{array}$ & $\begin{array}{l}3.8 \\
3.6 \\
3.8\end{array}$ & $\begin{array}{l}931 \\
930 \\
931\end{array}$ & $\begin{array}{l}140 \\
139 \\
140\end{array}$ & $\begin{array}{l}115 \\
114 \\
114\end{array}$ & $\begin{array}{l}11.4 \\
11.4 \\
11.5\end{array}$ & .0 & 0.0 & $\begin{array}{l}-2 \\
-12\end{array}$ & $\begin{array}{r}+1.9 \\
-2.3\end{array}$ & $\begin{array}{l}11910 \\
11880 \\
11930\end{array}$ & $\begin{array}{l}-30 \\
+50\end{array}$ \\
\hline
\end{tabular}

* 0 - just before application of the current.

1 -minute after application of the current (at cessation of convulsion).

3 -minutes after application of the current.

$\uparrow$ The serum water was calculated from the formula described in the section on Methods.

\section{RESULTS}

Table I presents the observed and calculated data from nine electroshock convulsive episodes in five women and four men unmodified by curare. It is clear that there was a sharp rise in the concentrations of sodium, chloride, potassium and total proteins in the serum during the one minute between the application of the electroshock and the cessation of the convulsion. The rise in concentrations of sodium and chloride in the serum were proportional and varied from 6.0 to $16.0 \mathrm{mEq} / \mathrm{L}$ in the case of sodium, and from 3.0 to $9.0 \mathrm{mEq} / \mathrm{L}$ in the case of chloride. However, the increases in the concentrations of potassium were proportionately greater than those of either sodium or chloride, varying from 0.3 to $2.6 \mathrm{mEq} / \mathrm{L}$. The concentrations of serum total proteins likewise rose in the same period. The change in chloride space calculated as a percentage of the assumed original volume varied from -4.3 to -9.7 per cent.

The concentrations of sodium, chloride and total proteins in the serum had closely approached the original pre-convulsion levels two to four minutes after the cessation of the convulsion. Likewise, the chloride space had re-expanded to a volume almost as large as the pre-convulsion value. At the two to four minute post-convulsion point, however, the concentration of serum potassium had fallen below its initial value in all but two patients.

It can be calculated that the total milliosmols in the body water increased during the convulsion period by from 570 to 1250 milliosmols or from 4.8 to 9.1 per cent. Within two minutes after the end of the convulsion a distinct decrease was detectable, and by the end of four minutes the original state had been restored.

The calculated exchanges of sodium between cellular and extracellular water were small and not consistent in direction. During the period of the convulsion there was a small, but almost always significant, movement of potassium from the cells to the extracellular space. In the two to four minutes following the convulsion there was a consistent movement of potassium into cells which, in all but one study, was distinctly larger than the loss from the cells during the convulsion.

Table. II presents the data observed in the first five patients when the electroshock convulsion 
was modified by curare. In four patients all the changes were qualitatively similar to those observed in the unmodified convulsion, but distinctly smaller. In Patient 5, whose convulsion was almost completely abolished by the curare, there were no significant changes.

\section{DISCUSSION}

The rise in concentrations of sodium and chloride of the serum at the end of the convulsion appears to be related to a contraction of the volume of the extracellular water, owing to a transfer of water from the extracellular to the intracellular compartment. The increase of serum protein indicates that this is accompanied by hemoconcentration. Since the movements of water between extracellular and intracellular compartments are dictated by osmotic pressure, the osmolar concentration within the cells must have increased. It is appreciated that precise estimates of the magnitude of these transfers throughout the body cannot be derived from analyses of blood from the antecubital vein. In phenomena of such a catastrophic order general equilibrium is not attained. It is reasonable to assume, especially in the light of the experiments with curare, that muscular activity is the responsible agent and that the transfers :are of the general order indicated. This view is further supported by the uniform nature of the restoration curves which were more gradual. It is also justifiable to infer that these catastrophic changes were not attended by appreciable movements of sodium or chloride into the cells.

The two sources of increase of the concentration of osmotically active constituents within the cells during the violent muscular exercise of a convulsion are the accumulation of acids within the cells and the breakdown of large complex organic molecules into more numerous smaller components. The first of these is related to the large buffer activity of the base-protein complexes. This is comparable to the sharp increase in water content in red blood cells when the serum is acidified (11), but in contrast to the very small increase in intracellular water of muscle reported when the extracellular fluid is acidified (12). The precise reasons for this difference in behavior are not completely understood but may largely be related to the facts that the muscle cell is not permeable to bicarbonate and chloride as is the red blood cell. However, in the present instance it is the internal milieu of the cell to which large amounts of acid have been added and the cellular base-protein buffer activity must result in an increase in osmolar concentration.

The fact that there is a reversal to the pre-shock distribution of water within a few minutes can be explained by the operation of two mechanisms. Many of the new smaller compounds are probably rapidly resynthesized to the larger, more complex but necessarily less numerous molecules. In addition, a large number of the newly formed small molecules may actually be able to cross the cell membrane, thus failing to exert an effective osmotic pressure. However, if they can permeate the cell membrane, they must move with a significantly slower speed than water, and therefore only transiently set up an osmotic gradient that demands the movement of water into the cells. The removal of acids from the cells would also reduce the osmolar concentration.

The movement of potassium from the cells during the convulsion may result from the liberation of potassium previously associated with large organic complexes that have broken down into more simple molecules. The return of potassium to the cells during the recovery period is probably related to the re-introduction of this ion into the resynthesized large organic complexes. It is not clear, however, why a larger amount of potassium moves into the cells during the recovery period. It may be related to a mechanism for the transfer of glucose from the extracellular fluid to the cells.

The demonstration that primary changes in osmolar concentration of this magnitude within the cells can occur and must of necessity cause a shift of water into the cells, and secondarily, a change in electrolyte concentration in the extracellular water provides a sound basis for the consideration of the possible role of such a mechanism in certain disease states. A chronically increased cellular osmolar concentration would be a plausible mechanism for the occurrence of hypernatremia in certain cerebral disorders $(13,14)$. Likewise, a chronically decreased cellular osmolar concentration might be the original defect in those instances of hyponatremia frequently observed among patients with pulmonary tuberculosis and other debilitated states (15-18). These so-called "saltwasting syndromes" may not represent a deple- 
tion of sodium in any true sense. The excretion of sodium and negative balance of this ion at reduced concentrations of sodium in the serum may merely represent an attempt to reduce the tonicity of the extracellular fluids in conformity with the reduced osmolar concentration within the cells. This mechanism may even apply in some debilitated patients with severe congestive heart failure who have hyponatremia without evident loss of sodium from the body. In this instance the reduced tonicity of the extracellular water must be achieved by the dilution effect of retained water, since other factors operative in congestive failure cause an almost complete tubular reabsorption of filtered sodium.

\section{SUMMARY AND CONCLUSIONS}

The violent muscular activity of an electroshock convulsion is accompanied by a rapid redistribution of body water characterized by a contraction of the extracellular space. This is presumably a response to an increase in cellular osmolar concentration. The extracellular space re-expands within two minutes after the cessation of the convulsion. There are no significant exchanges of sodium between the cells and extracellular fluid. During the convulsion potassium leaves the cells and in the recovery phase a larger amount of this ion moves back into the cells.

The suggestion is made that primary and more chronic alterations in cellular osmolar concentrations may be the original defect responsible in certain states for hypo- and hypernatremia.

\section{ACKNOWLEDGMENT}

The authors are indebted to Dr. William F. Green, Superintendent of the Fairfield State Hospital for his kind cooperation throughout the course of this study, and to Miss Jane V. Lee for her technical assistance in the laboratory determinations.

\section{BIBLIOGRAPHY}

1. Gamble, J. L., Ross, G. S., and Tisdall, F. F., The metabolism of fixed base during fasting. J. Biol. Chem., 1923, 57, 633.

2. Peters, J. P., Transfers of water and solutes in the body. The Harvey Lectures 1937-38, p. 112.
3. Yannet, H., and Darrow, D. C., The effect of depletion of extracellular electrolytes on the chemical composition of skeletal muscle, liver, and cardiac muscle. J. Biol. Chem., 1940, 134, 721.

4. Elkinton, J. R., Winkler, A. W., and Danowski, T. S., Inactive cell base and the measurement of changes in cell water. Yale J. Biol. Med., 1944, 17, 384.

5. Ward, J. R., and Call, L. S., Changes in blood chemistry in rats following electrically induced seizures. Proc. Soc. Exper. Biol. \& Med., 1949, 70, 381.

6. Altschule, M. D., and Tillotson, K. J., Effect of electroconvulsive therapy on water metabolism in psychotic patients. Am. J. Psychiat., 1949, 105, 829.

7. Hald, P. M., The flame photometer for the measurement of sodium and potassium in biological materials. J. Biol. Chem., 1947, 167, 499.

8. Elkinton, J. R., and Taffel, M., Prolonged water deprivation in the dog. J. Clin. Invest., 1942, 21, 787.

9. Gornall, A. G., Bardawill, C. J., and David, M. M., Determination of serum proteins by means of the biuret reaction. J. Biol. Chem., 1949, 177, 751.

10. Eisenman, A. J., Mackenzie, L. B., and Peters, J. P., Protein and water of serum and cells of human blood with a note on the measurement of red blood cell volume. J. Biol. Chem., 1936, 116, 33.

11. Van Slyke, D. D., Wu, H., and McLean, F. C., Studies of gas and electrolyte equilibria in blood; factors controlling the electrolyte and water distribution in the blood. J. Biol. Chem., 1923, 56, 765.

12. Hastings, A. B., and Eichelberger, L., Exchange of salt and water between muscle and blood; the effect of an increase in total body water produced by the intravenous injection of isotonic salt solutions. J. Biol. Chem., 1937, 117, 73.

13. Allott, E. N., Sodium and chloride retention without renal disease. Lancet, 1939, 1, 1035.

14. Luetscher, J. A., Jr., and Blackman, S. S., Jr., Severe injury to kidneys and brain following sulfathiazole administration; high serum sodium and chloride levels and persistent cerebral damage. Ann. Int. Med., 1943, 18, 741.

15. Winkler, A. W., and Crankshaw, O. F., Chloride depletion in conditions other than Addison's disease. J. Clin. Invest., 1938, 17, 6.

16. Westwater, J. O., Stiven, D., and Garry, R. C., A note on the serum sodium level in patients suffering from tuberculosis. Clin. Sc., 1939, 4, 73.

17. Gollan, F., Blood and extracellular fluid studies in chronic malnutrition in infancy. J. Clin. Invest., 1948, 27, 352.

18. Sims, E. A. H., Welt, L. G., Orloff, J., and Needham, J., Asymptomatic hyponatremia (non-Addisonian salt-wasting syndrome). Manuscript in preparation. 